\title{
Optimization of Waste Inertization Systems Based on Chemically Bonded Phosphate Ceramics
}

\author{
ELENA DUMITRESCU1*, ECATERINA ANDRONESCU², ALINA MONICA MARES ${ }^{2}$ \\ ${ }^{1}$ OMV PETROM S.A., ICPT Campina, 29 Culturii Blvd., Campina, Romania \\ 2Universitatea Politehnica Bucuresti, 1-4 Gh. Polizu Str., 011061, Bucuresti, Romania
}

\begin{abstract}
This paper presents the experimental results for optimization of the waste inertization systems based on Chemically Bonded Phosphate Ceramics (CBPCs). Through this process, the hazardous wastes containing heavy metals are transformed, by chemical reactions and binding in a solid matrix, into non-hazardous wastes. It was studied the obtaining mode of chemically bonded phosphate ceramics from magnesium oxide and potassium dihydrogen phosphate. Since the CBPCs system is a fast setting system it was studied the effect of retarders (boric acid and calcium lignosulphonate) used in concentrations of 1, 2 and 3\% (based on the amount of magnesium oxide and potassium dihydrogen phosphate) above the setting process. It was determined the setting time and compressive strength of the obtained samples. The optimal variant has been established to obtain a suitable material in terms of both mechanical and compositional properties.
\end{abstract}

Keywords: waste inertization, chemically bonded phosphate ceramics, wastes stabilization, wastes solidification

Environmental protection is a matter of greatimportance that must be treated very seriously, both internationally as well as nationally [1].

In the recent years, many researches have been carried out for solid waste treatment using the Stabilization/ Solidification (S/S) method [2].

Stabilization of wastes involves the chemical immobilisation of hazardous constituents by binding into a matrix, or chemical conversion to an immobile species, reducing leachability to the environment.

Stabilization/Solidification (S/S) processes are suitable for the treatment of difficult wastes. It is one of the most used techniques, because it is relatively simple, cheap and efficient.

A typical non-thermal stabilization treatment for wastes containing inorganic contaminants is chemical immobilization.

In order to stabilize/solidify inorganic wastes, chemically bonded phosphate ceramics (CBPCs) may be used [3]. CBPCs are unique materials because are formed atroom temperature as like a Portland cement, buthave the properties of a thermally treated ceramics. CBPC resistance is due to the mode of formation - by acid-base reactions, which produce strong covalentbonds compared with weaker bonds made by simply cement hydration [4]. CBPC is a solid, hard, dense ceramic material that incorporates waste into a mechanically, chemically and thermally resistant crystalline matrix. This material is formed by exothermic reaction between magnesium oxide ( $\mathrm{MgO}$ ) and potassium dihydrogen phosphate $\left(\mathrm{KH}_{2} \mathrm{PO}_{4}\right)$. The $\mathrm{MgO}$ is calcined to reduce its reactivity.

$$
\mathrm{MgO}+\mathrm{KH}_{2} \mathrm{PO}_{4}+5 \mathrm{H}_{2} \mathrm{O}=\mathrm{KMgPO}_{4} \cdot 6 \mathrm{H}_{2} \mathrm{O}
$$

The process takes place in three stages [5]:

- reaction of oxides and salt formation by hydrolysis; magnesium oxide reacts with the acid phosphate solution and forms positive aquasols;

- acid-base reaction and gel formation by condensation; positive aquasols react with phosphate anions to form a hydrophosphate gel;
- gel transformation into ceramic material; the saturated gel crystallizes around the unreacted metallic oxide granules in a crystalline network, with the formation of a monolithic ceramic.

Due to its high solubility and high rate of dissociation, magnesium oxide tends to react spontaneously with acid phosphate, forming precipitates. However, when this oxide is calcined [6] at temperatures above $1000^{\circ} \mathrm{C}$, are produced excellent ceramics.

Calcination of $\mathrm{MgO}$ reduces the solubility of $\mathrm{MgO}$ powder by reducing the porosity and permeability of the individual granules and, also increases the particle size. Significant reduction of surface area is the reason for the reduced solubility of the calcined $\mathrm{MgO}$ powder. Less reactive magnesium oxide results in a more compact microstructure for CBPCs [7].

Even if calcined MgO is used, the mixing time before setting occurs is only a few minutes, so retarders are required. If the reaction is too fast, itproduces a precipitate and nota ceramic material. Retarders such as boric acid $\left(\mathrm{H}_{3} \mathrm{BO}_{3}\right)[8,9]$ orcalcium lignosulfonate (LSC) have to be used.

When a very small amount of boric acid is added, a film develops on $\mathrm{MgO}$ particles that delay dissolution, thus delaying the acid-base reaction. Boric acid helps to develop a polymer film on $\mathrm{MgO}$ granules and thus slows the reaction speed.

By X-ray diffraction spectroscopy (XRD), the polymer covering the $\mathrm{MgO}$ particles is identified as lunebergite $\left[\mathrm{Mg}_{3} \mathrm{~B}_{2}\left(\mathrm{PO}_{4}\right)_{2}(\mathrm{OH})_{6} \cdot 6 \mathrm{H}_{2} \mathrm{O}\right]$ [5], which temporarily covers the surface of the magnesium oxide particles and prevents its dissolution in acid solution. When the $\mathrm{MgO}$ powder is mixed in solution, the pH increases and the layer which it covers (lunebergite) is dissolved. Thus, an improvement in workability is achieved by the addition of boric acid [10].

Calcium lignosulfonate (LSC) is a fluidizing agent that has a dispersing action, preventing the formation of coagulating, viscous structures, without significantly affecting the hydration processes, thus delaying the setting [11].

CBPCs can be used for inertization of liquid and solid toxic wastes which cannot be reduced destroyed or

\footnotetext{
* email: elena.dumitrescu2@petrom.com; Phone: (+40) 733991135
} 
recycled [12-20]. Through this process, heavy metal ions react with phosphate ions to form insoluble phosphates which are binding in a solid matrix, thus hazardous wastes are transformed into non-hazardous wastes.

\section{Experimental part}

The following experimental steps were performed to optimize CBPC:

- magnesium oxide ( $\mathrm{MgO})$ was calcined at different temperatures: $1100^{\circ} \mathrm{C}, 1200^{\circ} \mathrm{C}$ and $1300^{\circ} \mathrm{C}$ :

- because the system has rapid setting, the influence of various concentrations of retarders, such as boric acid and calcium lignosulfonate has been studied; $1 \%, 2 \%$ and $3 \%$ retarders were used, based on the amount of solid components ( $\left.\mathrm{MgO}+\mathrm{KH}_{2} \mathrm{PO}_{4}\right)$;

- the maximum temperature, the setting time and the compressive strength of the systems obtained were determined. X-ray diffraction was used for compositional characterization;

- the optimal variant has been established to obtain a suitable material from the point of view of mechanical properties by optimizing the composition.

\section{Sample preparation}

The following raw materials were used:

- magnesium oxide ( $\mathrm{MgO}$ ) calcined at temperatures of 1100, 1200 and $1300^{\circ} \mathrm{C}$;
- potassium dihydrogen phosphate $\left(\mathrm{KH}_{2} \mathrm{PO}_{4}\right)$;

- boric acid $\left(\mathrm{H}_{3} \mathrm{BO}_{3}\right)$ and calcium lignosúlfonate (LSC) as retarders;

- water;

- plastic cylindrical forms with the diameter equal with height $(4 \mathrm{~cm})$, which were used to pour the obtained compositions.

Magnesium oxide and potassium dihydrogen phosphate were dry mixed in a molar ratio of $1: 1$, followed by addition of retardants (boric acid or boric acid and LSC) and finally water was added. The obtained samples were continuously mixed with a glass rod, recording the maximum temperature reached by the system and the setting time.

Samples were poured in cylindrical forms, and after 21 days the compressive strength was measured to establish the cohesiveness of the materials. It also represents the efficiency of solidification and stabilization of the waste with the binder.

The samples were analyzed by X-ray diffraction to determine if the desired component was obtained: $\mathrm{KMgPO}_{4} \cdot 6 \mathrm{H}_{2} \mathrm{O}$.

Several compositions were prepared, shown in tables 1,2 and 3.

Table 1

COMPOSITIONS FOR SAMPLES PREPARED WITH MgO CALCINED AT $1100^{\circ} \mathrm{C}$

\begin{tabular}{|c|c|c|c|c|c|c|c|c|}
\hline $\begin{array}{c}\text { Sample } \\
\text { code }\end{array}$ & $\begin{array}{c}\mathrm{MgO}, \\
\% \text { gr. }\end{array}$ & $\begin{array}{c}\mathrm{KH}_{2} \mathrm{PO}_{4}, \\
\% \text { gr. }\end{array}$ & $\begin{array}{c}\text { Water, } \\
\% \text { gr. }\end{array}$ & $\begin{array}{c}\mathrm{H}_{3} \mathrm{BO}, \\
\% \text { gr. }\end{array}$ & $\begin{array}{c}\text { LSC, } \\
\% \text { gr. }\end{array}$ & $\begin{array}{c}\text { Maximum } \\
\text { temperature, }{ }^{\circ} \mathrm{C}\end{array}$ & $\begin{array}{c}\text { Setting time, } \\
\text { minutes }\end{array}$ & $\begin{array}{c}\text { Compressive } \\
\text { strength, } \\
\mathrm{MPa}\end{array}$ \\
\hline $\mathrm{I}$ & 11.90 & 40.48 & 47.62 & - & - & 66.5 & 2 & 0.72 \\
\hline I-1 & 11.84 & 40.27 & 47.37 & 0.52 & - & 64 & 9 & 1.37 \\
\hline I-2 & 11.78 & 40.06 & 47.13 & 1.04 & - & 58 & 15 & 2.99 \\
\hline I-3 & 11.72 & 39.85 & 46.88 & 1.55 & - & 53 & 23 & 6.86 \\
\hline I-A & 11.66 & 39.65 & 46.64 & 1.54 & 0.51 & 55.4 & 18 & 4.27 \\
\hline I-B & 11.60 & 39.44 & 46.40 & 1.53 & 1.02 & 57 & 18 & 2.73 \\
\hline I-C & 11.54 & 39.24 & 46.17 & 1.52 & 1.52 & 58.5 & 19 & 6.03 \\
\hline
\end{tabular}

Table 2

COMPOSITIONS FOR SAMPLES PREPARED WITH MgO CALCINED AT $1200^{\circ} \mathrm{C}$

\begin{tabular}{|c|c|c|c|c|c|c|c|c|}
\hline $\begin{array}{c}\text { Sample } \\
\text { code }\end{array}$ & $\begin{array}{c}\mathrm{MgO}, \\
\% \text { gr. }\end{array}$ & $\begin{array}{c}\mathrm{KH}_{2} \mathrm{PO}_{4}, \\
\% \text { gr. }\end{array}$ & $\begin{array}{c}\text { Water, } \\
\% \text { gr. }\end{array}$ & $\begin{array}{c}\mathrm{H}_{3} \mathrm{BO}_{3}, \\
\% \text { gr. }\end{array}$ & $\begin{array}{c}\text { LSC, } \\
\% \text { gr. }\end{array}$ & $\begin{array}{c}\text { Maximum } \\
\text { temperature, }\end{array}$ & $\begin{array}{c}{ }^{\circ} \mathrm{C} \\
\text { Setting time, } \\
\text { minutes }\end{array}$ & $\begin{array}{c}\text { Compressive } \\
\text { strength, } \\
\mathrm{MPa}\end{array}$ \\
\hline II & 11.90 & 40.48 & 47.62 & - & - & 64.8 & 5 & 1.14 \\
\hline II-1 & 11.84 & 40.27 & 47.37 & 0.52 & - & 63 & 10 & 1.21 \\
\hline II-2 & 11.78 & 40.06 & 47.13 & 1.04 & - & 54 & 15 & 3 \\
\hline II-3 & 11.72 & 39.85 & 46.88 & 1.55 & - & 53 & 25 & 3.63 \\
\hline II-A & 11.66 & 39.65 & 46.64 & 1.54 & 0.51 & 54.1 & 20 & 3.3 \\
\hline II-B & 11.60 & 39.44 & 46.40 & 1.53 & 1.02 & 58.4 & 18 & 3.07 \\
\hline II-C & 11.54 & 39.24 & 46.17 & 1.52 & 1.52 & 53.3 & 16 & 5.87 \\
\hline
\end{tabular}

Table 3

COMPOSITIONS FOR SAMPLES PREPARED WITH MgO CALCINED AT $1300^{\circ} \mathrm{C}$

\begin{tabular}{|c|c|c|c|c|c|c|c|c|}
\hline $\begin{array}{c}\text { Sample } \\
\text { code }\end{array}$ & $\begin{array}{c}\mathrm{MgO}, \\
\% \text { gr. }\end{array}$ & $\begin{array}{c}\mathrm{KH}_{2} \mathrm{PO}_{4}, \\
\% \text { gr. }\end{array}$ & $\begin{array}{c}\text { Water, } \\
\% \text { gr. }\end{array}$ & $\begin{array}{c}\mathrm{H}_{3} \mathrm{BO}_{3}, \\
\% \text { gr. }\end{array}$ & $\begin{array}{c}\text { LSC, } \\
\% \text { gr. }\end{array}$ & $\begin{array}{c}\text { Maximum } \\
\text { temperature, }{ }^{\circ} \mathrm{C}\end{array}$ & $\begin{array}{c}\text { Setting time, } \\
\text { minutes }\end{array}$ & $\begin{array}{c}\text { Compressive } \\
\text { strength, } \\
\mathrm{MPa}\end{array}$ \\
\hline III & 11.90 & 40.48 & 47.62 & - & - & 60.9 & 10 & 1.41 \\
\hline III-1 & 11.84 & 40.27 & 47.37 & 0.52 & - & 55.9 & 22 & 1.63 \\
\hline III-2 & 11.78 & 40.06 & 47.13 & 1.04 & - & 50.5 & 42 & 2.85 \\
\hline III-3 & 11.72 & 39.85 & 46.88 & 1.55 & - & 50.3 & 49 & 5.16 \\
\hline III-A & 11.66 & 39.65 & 46.64 & 1.54 & 0.51 & 49.6 & 54 & 6.26 \\
\hline III-B & 11.60 & 39.44 & 46.40 & 1.53 & 1.02 & 53.2 & 53 & 6.69 \\
\hline III-C & 11.54 & 39.24 & 46.17 & 1.52 & 1.52 & 51.2 & 41 & 6.48 \\
\hline
\end{tabular}




\section{Results and discussions}

For systems containing MgO, $\mathrm{KH}_{2} \mathrm{PO}_{4}$ and water (without retarders addition), the following were found:

- the maximum temperature of the obtained systems decreased with the increasing of the magnesium oxide calcination temperature, the lowest temperature being about 60 degrees, for the system that used calcined MgO for $3 \mathrm{~h}$ at $1300^{\circ} \mathrm{C}$;

- the setting time increased as the $\mathrm{MgO}$ calcination temperature increased, from $2 \mathrm{~min}$ (for the system with $\mathrm{MgO}$ calcined at $1100^{\circ} \mathrm{C}$ ) to $10 \mathrm{~min}$ (for the system with $\mathrm{MgO}$ calcined at $1300^{\circ} \mathrm{C}$ );

- the compressive strength increased as the MgO calcination temperature increased, from $0.72 \mathrm{MPa}$ (for the system with $\mathrm{MgO}$ calcined at $1100^{\circ} \mathrm{C}$ ) to $1.41 \mathrm{MPa}$ (for the system with $\mathrm{MgO}$ calcined at $1300^{\circ} \mathrm{C}$ ).

For systems containing $\mathrm{MgO}, \mathrm{KH}_{2} \mathrm{PO}_{4}$, water and boric acid as retarder, the following were found:

- the maximum temperature of the obtained systems decreased with the increase of the added boric acid concentration, the lowest temperature being about 50 degrees, for the system using $3 \%$ boric acid (based on the amount of $\mathrm{MgO}+\mathrm{KH}_{2} \mathrm{PO}_{4}$ ) and $\mathrm{MgO}$ calcined for 3 hours at $1300^{\circ} \mathrm{C}$ - sample $I I I^{2}-3$;

-the setting time increased with the increasing of the added boric acid concentration and the increasing of the $\mathrm{MgO}$ calcination temperature: from $23 \mathrm{~min}$ (for the system with $3 \%$ boric acid and $\mathrm{MgO}$ calcined at $1100^{\circ} \mathrm{C}$ ) to 49 minutes (for the system with 3\% boric acid and $\mathrm{MgO}$ calcined at $1300^{\circ} \mathrm{C}$ ). It can be seen that the setting time is very close for the systems with $\mathrm{MgO}$ calcined at $1100^{\circ} \mathrm{C}$ and $1200^{\circ} \mathrm{C}$; for the system with $\mathrm{MgO}$ calcined at $1300^{\circ} \mathrm{C}$ the time increases significantly;

-the compressive strength increased with increasing of added boric acid concentration, the highest values being recorded for systems with 3\% boric acid (based on the amount of $\mathrm{MgO}+\mathrm{KH}_{2} \mathrm{PO}_{4}$ ).

For systems containing $\mathrm{MgO}, \mathrm{KH}_{2} \mathrm{PO}$, water, boric acid and calcium lignosulphonate as retarders, the following were found:
- with the progressive addition of calcium lignosulfonate, there is a slight increase in the temperature of the obtained systems;

- the setting time slightly decreased as the amount of added lignosulfonate increased;

- the addition of a second retarder (LSC) does notimprove the mechanical properties; the compressive strength did not show significant increases compared to system without calcium lignosulfonate.

The highest compressive strength $(6.86 \mathrm{MPa})$ was recorded for the sample code $1-3$, which uses calcined $\mathrm{MgO}$ for $3 \mathrm{~h}$ at $1100^{\circ} \mathrm{C}$, potassium dihydrogen phosphate and boric acid at a concentration of 3\% (based on the amount of $\mathrm{MgO}+\mathrm{KH}_{2} \mathrm{PO}_{4}$ ).

In terms of setting time, it was found that systems using $\mathrm{MgO}$ calcined at 1100 and $1200^{\circ} \mathrm{C}$ show close values (up to 20-25 min), while for the system with $\mathrm{MgO}$ calcined at $1300^{\circ} \mathrm{C}$ the time is approximately twice bigger.

The mineralogical composition of the samples obtained was evaluated by $\mathrm{X}$-ray diffraction and it was observed that the desired component $\left(\mathrm{KMgPO}_{4} \cdot 6 \mathrm{H}_{2} \mathrm{O}\right)$ in $\mathrm{CBPC}$ was formed in all samples.

The figure 1 shows the X-ray diffraction pattern for sample I-3.

According to the USEPA [21] regulations, solidified and stabilized waste products must have a minimum unconfined compressive strength of $50 \mathrm{psi}(0.35 \mathrm{MPa})$ after 28 days. It has been established that a minimum strength of 50 psi or more is suitable strength for stabilized materials to support pressure of loads placed on them in the landfill.

From the compressive strength point of view of the, the highest value was obtained for system $I-3$, prepared from $\mathrm{KH}_{2} \mathrm{PO}_{4}, \mathrm{MgO}$ calcined at $11000^{\circ} \mathrm{C}, 3 \% \mathrm{H}_{3} \mathrm{BO}_{3}$ (based on the amount of $\mathrm{MgO}+\mathrm{KH}_{2} \mathrm{PO}_{4}$ ) and water. The setting time for this system is about $20 \mathrm{~min}$ (sufficient to ensure material workability) and this option is considered to be optimal for CBPCs obtaining.

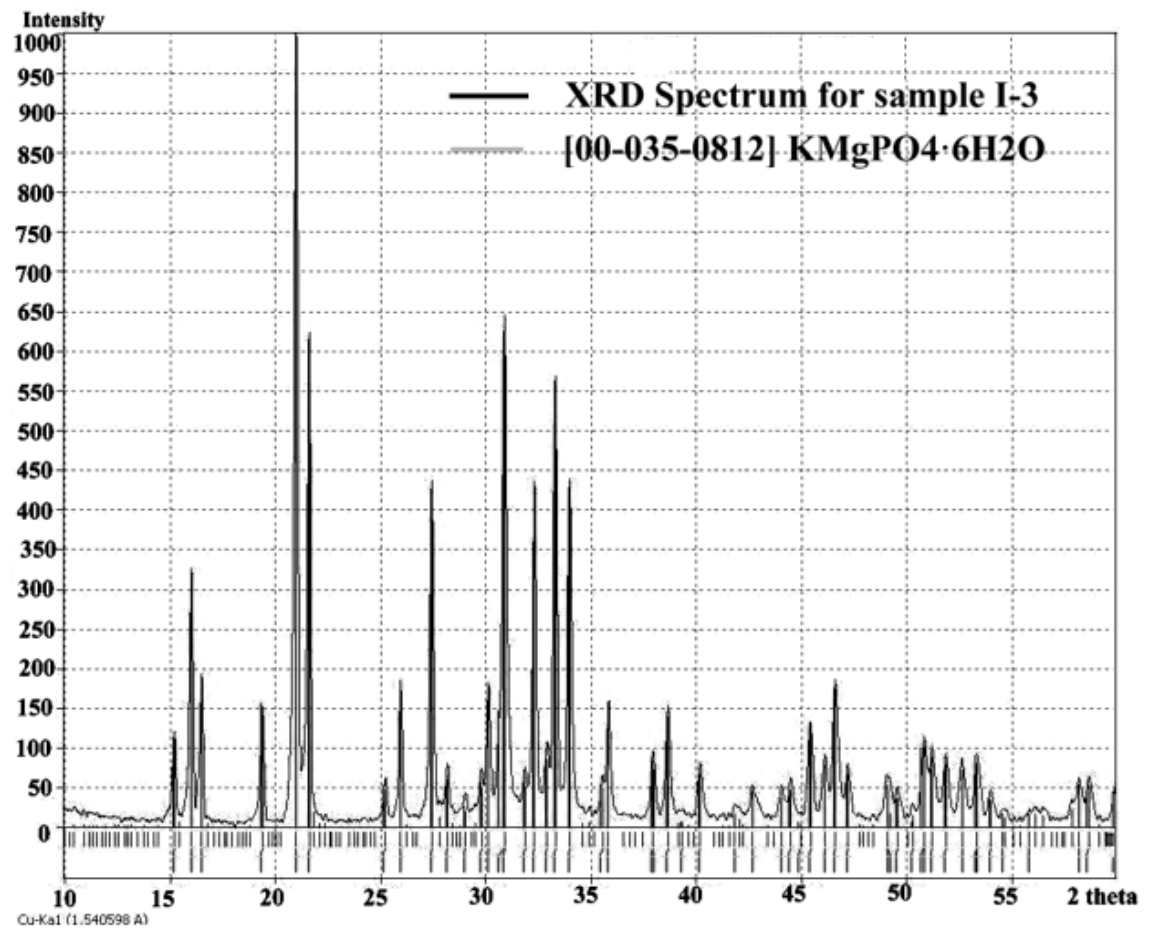

Fig. 1. XRD spectrum for sample $1-3$ 


\section{Conclusions}

By studying in laboratory of the obtaining of Chemically Bonded Phosphate Ceramics (CBPCs) it was established that the optimal variant are the following:

- magnesium oxide $(\mathrm{MgO})$ calcined at $1100^{\circ} \mathrm{C}$ and potassium dihydrogen phosphate $\left(\mathrm{KH}_{2} \mathrm{PO}_{4}\right)$, were dry mixed in a molar ratio of 1:1;

- then was added 3\% boric acid (based on the amount of solids $\mathrm{MgO}+\mathrm{KH}_{2} \mathrm{PO}_{4}$ ), which acted as a retarder;

- at the end was added water and mixed continuously about 20 min.

\section{References}

1.CHIVU, O.R., SEMENESCU, A., BABIS, C., IACOBESCU, G., NEGOITA, O.D., GRADINARU, S., Rev. Chim. (Bucharest), 68, no. 8, 2017, p.1858. 2.BENLAMOUDI, A., KADIR, A.A., TITU, M.A., ABDULLAH, M.M.A., SANDU, A.V., Rev. Chim. (Bucharest), 68, no. 8, 2017, p.1908.

3.J EONG S.Y., WAGH A.S., https://www.researchgate.net/publication/ 228391636, 2002.

4.WAGH, A.S., http://dx.doi.org/10.1155/2013/983731, 2013.

5.WAGH, A.S., JEONG, S.Z., J. Am. Ceram. Soc., 86(11), 2003, p.1838

6.WAGH, A.S., Chemically Bonded Phosphate Ceramics - 2nd Edition, Ed. Elsevier, 2016, $422 \mathrm{p}$.

7.VIANI, A., RADULESCU, A., PEREZ-ESTEBANEZ, M., Mater.Lett., 161, 2015, p. 628

8.*** Solidification/Stabilization-Resource Guide, Environmental Protection Agency, US-EPA, Office of Solid Waste and Emergency Response, 1999, 85p.
9.RIBEIRO, D.V., AGNELLI, J.A.M., MORELLI M. R., J. Mater. Res., 16(5), 2013, p. 1113.

10.FORMOSA, J., CHIMENOS, J.M., LACASTA, A.M., NIUBO, M., Ceram. Int., 38(3), 2012, p. 2483.

11.MACOVEI, N.I., Fluide de foraj i cimenturi de sonda, Vol. I, Ed. UPG, 1993, $210 \mathrm{p}$.

12.BU , I., TORRAS, J., CASELLAS, D., ROVIRA, M., PABLO, J ., J. Hazard. Mater., 170(1), 2009, p. 345

13.MIGNARDI, S., CORAMI, A., FERRINI, V., Chemosphere, 86(4), 2012, p. 354

14.CAO, X., WAHBIC, A., MA, L., LI, B., YANG, Y., J. Hazard. Mater., 164(2-3), 2009, p. 555

15.DU, Y.J., WEI, M.L., REDDY, K.R, JIN, F., WU, H.L., LIU, Z.B., J. Environ. Manage., 146, 2014, p.179

16.KOGBARA, R.B., AL-TABBAA, A., IYENGAR, S.R., Water, Air, Soil Pollut., 216, , no. 1, 2011, p. 411

17.ZHEN, S., DONG, X., APPIAH-SEFAH, G., J. Appl. Sci. Eng. (JASE), 17(4), 2014, p. 413.

18.YANG, Q., WU, X., Cem. Concr. Res., 29(3), 1999, p.389.

19.DUMITRESCU E., ANDRONESCU E., Romanian J ournal of Materials, 46, no. 2, 2016, p. 175

20.DUMITRESCU E., ANDRONESCU E., Romanian J ournal of Materials, 46, no. 1, 2016, p. 102

21.*** US EPA OSWER Directive No. 9437.00-2A, USEPA 1989.

Manuscript received: 27.03 .2018 